$10 / 211^{-92} g 5(1)$

-

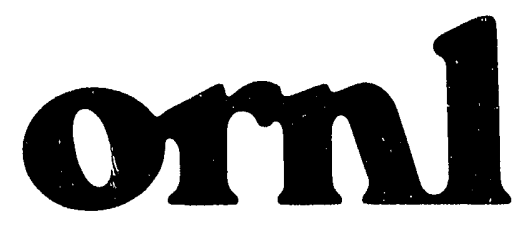

ORNL/TM-11853/R1

OAK RIDGE

NATIONAL

LABORATORY

MARTIN MARIETTA

\title{
Waste Reduction Plan for Oak Ridge National Laboratory
}

\author{
Prepared by
}

ORNL Waste Management Staff

MARTIN MARIETTA ENERGY SYSTEMS, INC. 
This report has been reproduced directly from the best available copy.

Available to DOE and DOE contractors from the Office of Scientific and Technical Information, P.O. Box 62, Oak Ridge, TN 37831; prices available from (615) 576-8401, FTS 626-8401.

Available to the public from the National Technical Information Service, U.S. Department of Commerce, 5285 Port Royal Rd., Springfield, VA 22161.

This report was prepared as an account of wurk sponsored by an agency of the United States Government. Neither the United States Government nor any agency thereof, nor any of their employees, makes any warranty, express or implied, or assumes any legal liability or responsibility for the accuracy, completeness, or usefulness of any information, apparatus, product, or process disclosed, or represents that its use would not infringe privately owned rights. Reference herein to any specific commercial product, process, or service by trade name, trademark, manufacturer, or otherwise, does not necessarily constitute or imply its endorsement, recommendation, or favoring by the United States Government or any agency thereof. The views and opinions of authors expressed herein do not necessarily state or reflect those of the United States Government or any agency thereof. 
ORNL/TM-11853/R1

ORNL/TM- $-11853 / \mathrm{R} 1$

DE92 007402

Waste Reduction Plan

for

Oak Ridge National Laboratory

December, 1991

Prepared for:

Oak Ridge National Laboratory

Oak Ridge, Tennessee 37831 managed by

Martin Marietta Energy Systems, Inc.

for the

U.S. Department of Energy

prepared by:

ORNL Waste Management Staff

Approved: MWRanenthy $\frac{12 / 20 / 91}{\text { Date }}$ 
TABILE OF CONTENTS

ACRONYM LIST

1. INTRODUCTION $\ldots \ldots \ldots \ldots \ldots \ldots \ldots \ldots \ldots \ldots \ldots \ldots \ldots \ldots \ldots \ldots \ldots$

2. OBJECTIVES OF THE ORNL WASTE REDUCTION PROGRAM $\ldots \ldots \ldots, 2$

2.1. MANAGEMENT COMMITMENT $\ldots \ldots \ldots \ldots \ldots \ldots \ldots \ldots \ldots, 2$

2.2. PROGRAM SCOPE AND OBJECTIVES $\ldots \ldots \ldots \ldots \ldots \ldots \ldots \ldots \ldots$

2.3. PERFORMANCE GOALS $\ldots \ldots \ldots \ldots \ldots \ldots \ldots \ldots \ldots \ldots \ldots \ldots$

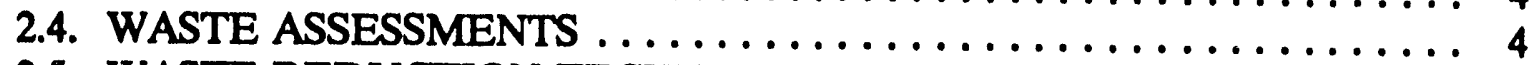

2.5. WASTE REDUCTION TECHNIQUES $\ldots \ldots \ldots \ldots \ldots \ldots \ldots \ldots \ldots$. 5

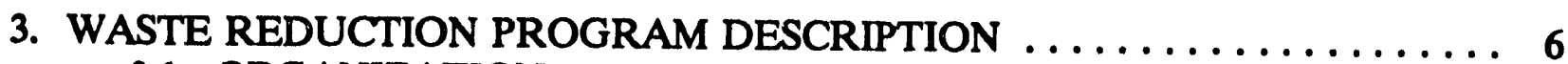

3.1. ORGANIZATION $\ldots \ldots \ldots \ldots \ldots \ldots \ldots \ldots \ldots \ldots \ldots \ldots \ldots \ldots \ldots$

3.2. ORGANIZATIONAL INTERFACES $\ldots \ldots \ldots \ldots \ldots \ldots \ldots \ldots, 7$

3.2.1. Internal Interfaces $\ldots \ldots \ldots \ldots \ldots \ldots \ldots \ldots \ldots \ldots \ldots, 7$

3.2.2. External Interfaces $\ldots \ldots \ldots \ldots \ldots \ldots \ldots \ldots \ldots \ldots, 8$

3.3. WASTE STREAM CATEGORIES $\ldots \ldots \ldots \ldots \ldots \ldots \ldots \ldots \ldots, \ldots$

3.3.1. Waste Stream Identification $\ldots \ldots \ldots \ldots \ldots \ldots \ldots \ldots \ldots, 9$

3.4.2. Tracking Systems ...................... 10

3.4. WASTE MANAGEMENT COST ACCOUNTING $\ldots \ldots \ldots \ldots \ldots \ldots 11$

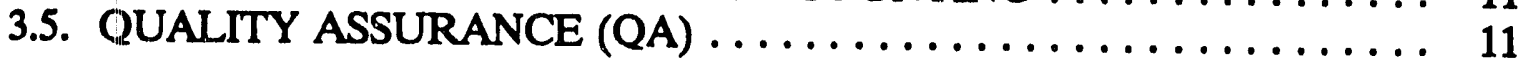

4. WASTE REDUCTION ACTIVITIES $\ldots \ldots \ldots \ldots \ldots \ldots \ldots \ldots \ldots \ldots \ldots, 12$

4.1. WASTE REDUCTION INCENTIVES $\ldots \ldots \ldots \ldots \ldots \ldots \ldots \ldots \ldots \ldots, 12$

4.1.1. DOE-OR Waste Minimization Awards ............... 12

4.1.2. ORNL Waste Reduction Suggestion Program .......... 12

4.2. SPECIFIC EXAMPLES OF WASTE REDUCTION AT ORNL $\ldots \ldots \ldots 12$

4.2.1. Waste Avoidance/Volume Reduction ................ 12

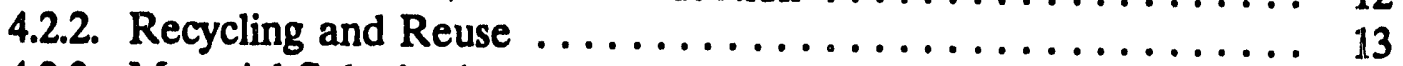

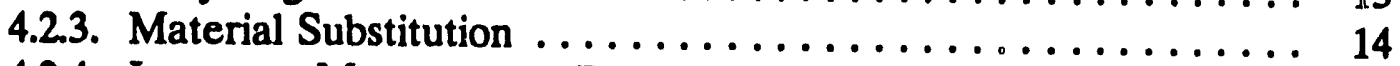

4.2.4. Inventory Management (Procurement Control) ........... 15

4.2.5. Material Substitution and Process Modifications ........... 15

4.2.6. Waste Segregation ........................... 17

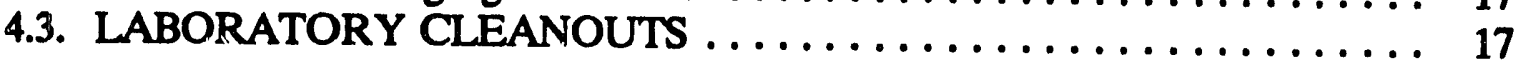

5. WASTE REDUCTION AWARENESS $\ldots \ldots \ldots \ldots \ldots \ldots \ldots \ldots \ldots \ldots \ldots, 18$

5.1. EMPLOYEE TRAINING $\ldots \ldots \ldots \ldots \ldots \ldots \ldots \ldots \ldots \ldots \ldots \ldots \ldots, 18$

5.2. COMMUNICATIONS $\ldots \ldots \ldots \ldots \ldots \ldots \ldots \ldots \ldots \ldots \ldots \ldots \ldots$

6. TECHINOLOGY TRANSFER $\ldots \ldots \ldots \ldots \ldots \ldots \ldots \ldots \ldots \ldots \ldots \ldots$

7. WASTE REDUCTION PROGRAM EVALUATION ............ 20

REFERENCES $\ldots \ldots \ldots \ldots \ldots \ldots \ldots \ldots \ldots \ldots \ldots \ldots \ldots \ldots \ldots \ldots \ldots \ldots \ldots \ldots \ldots$ 


\section{ACRONYM LIST}

\begin{tabular}{|c|c|}
\hline $\begin{array}{l}\text { ALARA } \\
\text { AVID }\end{array}$ & $\begin{array}{l}\text { as low as reasonably achievable } \\
\text { Accelerated Vendor Inventory Delivery (System) }\end{array}$ \\
\hline DOE & Department of Energy \\
\hline EPA & Environmental Protection Agency \\
\hline ESD & Environmental Sciences Division \\
\hline ES\&H & Environment Safety and Health \\
\hline F\&BM & Finance Business Management \\
\hline GCO & Generator Certification Official \\
\hline HMIS & Hazardous Materials Inventory System \\
\hline HQ & Headquarters \\
\hline HWTS & Hazardous Waste Tracking System \\
\hline IDB & Integrated Data Base \\
\hline LGTTG & Liquid Gaseous Treatment Technology Group \\
\hline LLLW & liquid low-level waste \\
\hline LLLLWC & liquid low-level waste concentrate \\
\hline LLW & low-level waste \\
\hline LSA & low specific activity \\
\hline NEPA & National Environmental Policy Act \\
\hline NRWTP & Nonradiological Wastewater Treatment Plant \\
\hline ORNL & Oak Ridge National Laboratory \\
\hline OR & Oak Ridge \\
\hline OWMRA & Office of Waste Management and Remedial Action \\
\hline PIP & Performance Improvement Process \\
\hline PPAP & Pollution Prevention Awareness Program \\
\hline PWA & Process Waste Assessment \\
\hline PWTP & Process Waste Treatment Plant \\
\hline $\begin{array}{l}\text { RCRA } \\
\text { R\&D }\end{array}$ & $\begin{array}{l}\text { Resource Conservation and Recovery Act } \\
\text { research and develonment }\end{array}$ \\
\hline REDC & Radiochemical Engineering Development Center \\
\hline SLLW & solid low-level waste \\
\hline SWIMS & Solid Waste Information Management System \\
\hline TRU & transuranic \\
\hline TSA & Technical Safety Appraisal \\
\hline WAC & waste acceptance criteria \\
\hline WIN & Waste Information Network \\
\hline VF & Waste Reduction Representa \\
\hline
\end{tabular}




\section{WASTE REDUCTION PLAN FOR \\ OAK RIDGE NATIONAL LABORATORY}

\section{INTRODUCTION}

Oak Ridge National Laboratory (ORNL) is a multipurpose research and development (R\&D) facility owned and operated by the Department of Energy (DOE) and managed under subcontract by Martin Marietta Energy Systems (Energy Systems), Inc. ORNL's primary role is the support of energy technology through applied research and engineering development and scientific research in basic and physical sciences. ORNL is also a valuable resource in the quest to solve problems of national importance, such as nuclear and chemical waste management. In addition, ORNL produces useful radioactive and stable isotopes for medical applications and energy research that are unavailable from the private sector.

ORNL R\&D activities generate numerous small waste streams. In the hazardous waste category alone, over 300 streams of a diverse nature exist. Generation avoidance, reduction or recycling of wastes is an important goal in maintaining efficiency of ORNL R\&D activities and protection of workers, the public, and the environment.

Waste minimization is defined as any action that minimizes or eliminates the volume or toxicity of waste by avoiding its generation or recycling. This is accomplished by material substitution and inventory management, process modification, or recycling wastes for reuse. Waste reduction is defined as waste minimization plus treatment which results in volume or toxicity reduction. The ORNL Waste Reduction Program will include both waste minimization and waste reduction activities.

Planning for waste reduction has received considerable emphasis and will be an important consideration during the next decade. Federal regulations, DOE Orders and guidelines, increased costs and liabilities associated with the management of wastes, limited disposal options, facility capacities, resource conservation, and public consciousness have been motivating factors for developing and implementing comprehensive waste reduction programs.

The Environmental Protection Agency's (EP'A) Pollution Prevention and the Tennessee Hazardous Waste Acts of 1990 have added both guidance and regulatory mandates for waste stream analysis and waste reduction. In addition, DOE Orders and Martin Marietta Energy Systems policies espouse the reduction or elimination of waste. DOE Order 5820.2A, Chapter III. Section 3.c(2) requires DOE facilities to establish an auditable waste reduction program for all low level waste ( $L L W)$ gerierators ${ }^{1}$. In addition, it further states in Chapter III, Section 3.c(4) that any new facilities, or changes to existing facilities, incorporate waste minimization into design considerations. DOE Order, 5400.1, Chapter III, Section 4.b, requires the preparation of a waste reduction program plan which must be reviewed annually and updated every three years ${ }^{2}$. Implementation of a waste minimization program for hazardous and mixed waste categories; is cited in DOE Order 5400.3, Section 7.d(5) 


\section{OBJECTIVES OF THE ORNL WASTE REDUCTION PROGRAM}

A formal ORNL waste reduction program for the hazardous waste category has been in existence since mid-1985 when it was launched in response to the requirements of the Resource Conservation and Recovery Act (RCRA), Section 3002.4 The waste reduction plan required by DOE Order 5400.1 was expanded to include ORNL waste minimization and reduction reporting requirements for all waste categories generated. The goals of the ORNL Waste Reduction Program are to prevent pollution and reduce the volume, toxicity and mobility of all wastes generated and to ensure the protection of the environment and the health of the public and employees. Emphasis will be placed on waste streams that comprise a large or toxic portion of the waste generated at ORNL.

Most waste reduction programs are developed for production facilities, which typically have few streams with large volumes. Production facilities are, therefore, able to realize significant waste reduction through few, focused waste minimization or reduction efforts. ORNL is an R\&D facility having up to $\mathbf{3 0 0}$ hazardous wastes streams, most of which are generated in small quantities. In contrast to production facilities, the wide diversity of ORNL waste complicates both management and compliance with regard to reporting requirements. ORNL, as a facility of over 960 small laboratories, may experience difficulty seeing any single, large reductions even through the comprehensive Waste Reduction Program. However, collectively, significant waste reduction can be achieved by the strategy which is outlined in this plan. ORNL, by implementing this strategy, could realize significant benefit by reducing wastes that are operationally difficult to manage.

The basic strategy for waste reduction at ORNL is to (1) identify generators of voluminous or problem waste streams and implement projects to reduce those streams and (2) train and motivate all ORNL staff to incorporate waste reduction measures into their activities. The latter aspect targets the small, variable, diverse waste streams and is to be accomplished through workshops, posters, incentive programs, and ORNL policies.

As the waste reduction program is implemented, each ORNL division will conduct process waste assessments to identify target waste streams and processes for waste reduction efforts. As streams are targeted for waste reduction activity, funding will be requested and projectspecific, numeric waste reduction goals will be established.

\subsection{MANAGEMENT COMMITMENT}

Energy Systems and ORNL management are committed to the minimization of waste volumes, toxicity, and mobility. The Energy Systems' policy regarding waste minimization was initially issued in May 1986 . That policy reflected the company's commitment to a disciplined, rational approach to waste management. Furthermore, this policy conveyed Energy Systems' intent to implement comprehensive waste reduction programs that reduce the quantity and hazard of generated wastes. DOE and Energy Sysiems have a policy of total compliance with environmental, safety and health (ES\&H) laws and regulations, 
including RCRA mandated waste minimization. This position was reflected in a memorandum distributed to all ORNL employees (See Appendix A) from the ORNL Deputy Director to ORNL Division Directors renewing ORNL's commitment io waste reduction. Previously, all ORNL employees received a statement from the ORNL Director dated November 22, 1989, recognizing the need for pollution prevention. Furthermore, ORNL management provided funding from ORNL Overhead in February 1991 to bridge a gap in programmatic support for waste reduction for the remainder of FY 1991.

\subsection{PROGRAM SCOPE AND OBJECTIVES}

ORNL's waste reduction program focuses on all forms of waste. The scope of the program is a comprehensive, continual effort to reduce the generation of all waste streams. Although the waste reduction program addresses all waste streams, emphasis will be place on specific streams based on their volume or toxicity. The objective of a waste reduction program is to establish an organized approach to evaluate the reduction of waste generated at the source or to recycle waste resulting in a reduction of risk to human health, protection of the environment and the prudent use of resources. ORNL's Waste Reduction Program is designed to reduce environmental, health, safety, and financial liabilities while complying with Federal and state regulations, DOE orders, and company policies. These objectives were communicated to all employees in the policy letters discussed in Section 2.1.

The following are elements of the Waste Reduction Plan to meet the objectives stated. The elements are discussed in more detail throughout the plan.

o involve all ORNL employees in the waste reduction effort

o provide waste reduction training

- establish achievable, measurable waste reduction goals as part of each Division Director's annual measures of performance

o establish recycling programs

o establish waste tracking systems that are designed to evaluate waste reduction efforts

- prioritize the waste streams for waste reduction potential by conducting process waste evaluations

- conduct economic feasibility studies of potential waste reduction candidate waste streams

- obtain funding and establish schedules for the implementation of selected waste stream options

o establish a program of awards for waste reduction suggestions and accomplishments

o maintain open channels of communication

The overall success of the program will depend upon the continued commitment of management to the program, establishing and achieving realistic waste reduction goals, and the participation of ORNL, employees. 


\subsection{PERFORMANCE GOALS}

A priority of a waste reduction program is to establish reasonable waste reduction goals that are quantifiable and measurable. ORNL divisions will develop plans for reducing their waste generation by July 1, 1992. Using process waste assessments (PWAs) as guidelines, they will designate measurable performance goals and identify implementation schedules as part of their plan. Because ORNL is a R\&D institution and not a production facility, reduction goals will be based on previous year's generation data instead of per production unit. Divisions will be responsible for evaluating and prioritizing waste streams to achieve these goals.

In addition to division specific goals, Energy Systems has adopted the following goals in the ORNL ES\&H Management Plan for Oak Ridge National Laboratory ${ }^{s}$

To reduce the Superfund Amendments and Reauthorization Act (SARA) 313 toxic chemical releases to $50 \%$ of the 1988 level by 1995 , and to $5 \%$ of the 1991 level by the year 2000.

To reduce the level of 17 high priority toxic chemicals by $33 \%$ of the 1988 quantity by 1992 and by $50 \%$ by 1995 .

To reduce the emission of ozone depleting chemicals, and

To reduce solid waste disposal to $50 \%$ of the 1991 level by 1995 and to $25 \%$ by 2000 .

The ORNL Waste Reduction Program will coordinate waste reduction efforts for selected multi-division waste streams. Future updates of this plan will document specific goals for waste category and associated implementation schedules. Established goals for waste reduction will be subject to periodic review. The Program objective is to reduce the volume, toxicity, and mobility of all waste streams as much as is practical by establishing goals that are achievable, measurable, meaningful, acceptable, and maintain the appropriate balance between desired waste reduction and cost effectiveness.

ORNL's performance evaluation criteria, which were established for determining award fees including waste reduction goals and milestones, and thereby, provide an additional incentive.

\subsection{WASTE ASSESSMENTS}

In the past, the evaluation of waste generation has been division or waste specific. For example, Performance Improvement Process (PIP) teams have been formed to examine reduction opportunities for specific materials or division-wide wastes. Additionally, individuals, working with their supervision, have contributed to significant reductions in waste generation and recycling. However, in order to continue to formalize the waste reduction opportunities evaluation process, it was recognized that a more standardized evaluation 
cpportunities evaluation process, it was recognized that a more standardized evaluation p'ocess was needed. The guidance provided by DOE for conducting PWAs will be used as the foundation for opportunity assessments at ORNL. PWAs will be conducted as part of the ongoing program to identify, screen, and analyze options to reduce the generation of waste. A PWA determines the amount of material in a workplace that is disposed of as waste during normal work operations. It provides a summary of hazardous materials usage and waste production and helps identify those processes and operations that require improvement or replacement to promote waste reduction. The assessment provides a basis for prioritizing the specific modifications to site processes or other waste reduction options that are developed as a result of the assessment.

Guidance found in the DOE Waste Minimization Guidance for Process Waste Assessments ${ }^{6}$ and Environmental Protection Agency Manual for Waste Minimization Opportunity Assessments ${ }^{7}$ is used, as appropriate, in conducting the assessments. Completion of flow diagrams, material balances, and related narratives permit the identification of process inefficiencies that may be modified or corrected to reduce waste generation. These waste generator reduction opportunities will be evaluated and identified with specific projects to reduce the volume and toxicity of the waste streams. The PWA will culminate in a recommended option. These recommended options will be evaluated using the criteria outlined in the DOE Process Assessment Guide and site-specific knowledge followed by implementation of the preferred option.

\subsection{WASTE REDUCTION TECHNIQUES}

Waste reduction includes those activities that minimize or eliminate the generation of waste and recycling processes that use, reuse, or reclaim a material from a waste stream. The following activities are not considered to be waste reduction: The transfer of waste constituents from one environmental medium to another or dilution as a means of toxicity reduction (unless it is for the purpose of preparing the waste stream for future recycling). The following techniques are being employed to reduce the generation of waste:

Inventory Management: Current methods to control the types and quantities of materials in the site inventory will continue to be reviewed. Where necessary, inventory control techniques will continue to be revised and expanded to reduce inventory size and hazardous chemical use while increasing inventory turnover. In particular, inventory control techniques are continually used to reduce waste resulting from excess, out-of-date and no longer used raw materials. Incoming chemicals are marked with the delivery date to encourage employees to use older chemicals before they expire. Individual laboratories are also required to keep current logs of chemicals in stock. These lists are consulted before ordering new supplies.

The review of inventory management techniques include studying (1) how existing inventory management procedures can be applied more effectively, (2) whether new techniques should be added to or substituted for current procedures, (3) the need for review and evaluation 
of approval procedures for the purchase of materials, and (4) the need for additional employee training.

Maintenance Program: The site equipment maintenance program will be periodically reviewed to determine whether improvements in corrective and preventative maintenance can reduce waste generation caused by equipment failure. After the evaluation, a determination will be made as to whether maintenance procedures are contributing to the production of waste in the form of process materials, scrap, and cleanup residue. The need for the revision of operational procedures, equipment modification, source segregation, and recovery as they apply to maintenance will be periodically examined.

Material Substitution and Process Modification: The replacement, reformation, reduction, or elimination of hazardous materials in production, maintenance, and cleaning processes is continually examined. The effect of waste reduction by the installation of new equipment or the modification of existing equipment will continue to be considered. Techniques, such as segregation, to separate hazardous, radioactive and recoverable wastes from the total waste stream will be explored during PWA evaluations.

Recycling and Reuse: The recovery of wastes is used as an opion in the waste reduction program after first considering reducing the amount of waste generated at the source. Opportunities for reclamation and reuse of waste materials are explored whenever feasible. Decontamination of tools, equipment, and materials for reuse or recycle is used to the extent practicable to minimize the amount of waste for disposal.

\section{WASTE REDUCTION PROGRAM DESCRIPTION}

\subsection{ORGANIZATION}

ORNL has appointed a Waste Reduction Coordinator (WRC) to manage the program for waste reduction. The WRC resides administratively within the Office of Waste Management and Remedial Actions (OWMRA) as shown in Appendix B.

DOE-Oak Ridge (OR) Waste Management Division functions as the programmatic oversight for the Waste Reduction Program. DOE-Headquarters (HQ) Waste Management provides independent oversight of the Waste Reduction Program through audits and surveillances. Both the OWMRA and the Office of Environmental Compliance and Documentation (OECD) provide technical support in the review of division specific Waste Reduction Plans and implementation of procedures.

Since 1985, each ORNL waste generating division has had a Waste Reduction Representative (WRR). The WRRs are assigned by the respective Division Directors and serve as the waste reduction technology transfer point within their division. This responsibility includes providing information about the wastes generated within their division for reporting purposes; ensuring that new projects or changes to existing facilities have 
considered waste reduction in design or construction; and submitting ideas, problems, or nominations of waste reduction efforts originating within their division.

The WRC meets with the WRRs at least twice a year to exchange information, provide updates on waste reduction developments, discuss problems, elicit suggestions, and review the program. Informally, contact with the WRRs on waste reduction activities occurs on a more frequent basis. The list of current division Waste Reduction Representatives is maintained by the Waste Management Coordination and Planning Office.

\subsection{ORGANIZATIONAL INTERFACES}

\subsubsection{Internal Interfaces}

\section{As Low As Reasonably Achievable (ALARA) Program}

As for any ORNL operation, the ALARA principle must be considered when planning waste reduction. The ALARA and Waste Reduction Programs have common objectives. During the planning of any project or operation, consideration is given to reducing waste, protecting the safety and health of employees, and minimizing impacts to the environment. The ALARA Program is being expanded to include nonradioactive functions: Hazardous Chemicals ALARA. Waste reduction will play an important role in limiting the exposure of personnel to hazardous chemicals. In general, excessive waste results in excessive exposure to either radiation or hazardous chemicals and must be avoided by good planning.

\section{Capital Projects}

Any new capital project or change to an existing facility must consider potential waste generation as part of the project plans. Beginning in November 1989, the following waste minimization statement has been in the environmental protection documentation developed for each new project. Waste reduction will be included in the new National Environmental Policy Act (NEPA) documentation for all new projects at ORNL.

"As called for in DOE Order 5400.1 [Chapter III, Section 4, Part (b)], the Resource Conservation and Recovery Act [Section 1003, Part (a), Item (6)], and ORNL's Waste Reduction Plan, measures will be taken during both the construction and operational phases of the proposed project to implement waste minimization practices. Waste minimization includes actions such as source reduction (minimizing the generation of wastes), material substitution (using less hazardous materials), procurement control (purchasing only quantities required), recycling (reusing materials), and good housekeeping practices (e.g., preventing spills). Guidance regarding waste minimization will be obtained from the ORNL Waste Reduction Coordinator as early as feasible in the planning stages of the proposed project." 


\section{Certification Programs}

The certification program at ORNL has initiatives that include all categories of waste. Certification program objectives include improved waste stream characterization and segregation, coinciding with waste reduction objectives. Waste generator certification training is required, and the required training addresses waste reduction.

Development of the ORNL Waste Certification Programs is being closely coordinated with the Waste Reduction Program. Liquid low level waste (LLLW) and transuranic (TRU) waste Generator Certification Officers (GCOs) have been appointed to provide to OWMRA waste generation, characterization and processing information. Where appropriate, the information is used to determine methods for reducing waste generation.

\section{Pollution Prevention Awareness Program (PPAP)}

DOE Order 5400.1 specifies that a documented PPAP be part of each project's mission statements and project plans. The PPAP has formed an Implementation Planning Committee and Task Teams to develop, plan, and implement components of the PPAP. The PPAP has similar objectives to the Waste Reduction Program which are to instill awareness, disseminate information, provide training, rewards and encourage employee participation in solving environmental issues and pollution prevention. By sharing objectives, the two initiatives will coordinate activities where appropriate, e.g., inclusion of a combined PPAP and waste reduction statement in the project plan.

\section{PIP Program}

Waste reduction efforts and suggestions have been supported by the PIP Program. The PIP Program has studied waste reduction activities such as chemical dispersing stations, recycling oil, and paper recycling.

\subsubsection{External Interfaces}

\section{Other DOE Facilities}

Communications with other DOE facilities is accomplished by use of the Waste Information Network (WIN) system which has a waste minimization bulletin board and allows sites to exchange ideas, problems, and technology electronically; attending Waste Reduction workshops, conferences, seminars, and establishing contacts at other DOE sites to exchange waste reduction information. Information about ORNL's waste reduction training and Waste Reduction Program has been given to other facilities.

Other External Sources

ORNL has utilized and will continue to use the free waste minimization assessment resources from the University of Tennessee's Center for Industrial Services. The EPA has 
establisłied the Waste Reduction Resource Center of the Southeast which ORNL can use as a source for information and technology transfer.

\subsection{WASTE STREAM CATEGORIES}

All ORNL waste streams and operations are candidates for waste reduction assessments.

\subsubsection{Waste Stream Identification}

For purposes of the Waste Reduction Program, ORNL wastes are categorized as:

o hazardous wastes (including containerized gaseous wastes),

o mixed wastes (hazardous and radioactive)

o gaseous wastes (i.e., air emissions),

o TRU wastes,

o SLLW,

- LLLW,

- process waste, and

o industrial/sanitary/institutional waste.

Waste stream characterization plays an important role in both the waste reduction and certification programs. In order to apply waste reduction or certify a waste stream, the waste stream cilaracteristics must be known. Waste stream characterization will also determine if the composition is homogeneous or heterogenous, consistent over time or highly variable. For waste reduction efforts, this information will be obtained during PWAs. The data will be used to apply waste reduction technology, (i.e., process changes, recycling, and material substitution). Data will be shared between these programs to avoid duplication of effori.

The calendar year (CY) 1990 waste generation rates for all categories of waste, excluding gaseous, are given in Table 2. ORNL does not, at present, have quantitative information on gaseous effluents. Hazardous and mixed wastes generated during CY 1990 resulted in $75,397 \mathrm{~kg}$ from routine operations and $67,692 \mathrm{~kg}$ from nonroutine operations such as laboratory cleanout, spills, etc. Presently, the other wastes categories are not tracked as routine or nonroutine generation. 
Table 1. ORNL waste generation rates for CY $1990^{\circ}$

\begin{tabular}{|l|c|}
\hline \multicolumn{1}{|c|}{ Waste Category } & Waste Generation \\
\hline Hazardous & $131,629 \mathrm{~kg}$ \\
\hline Mixed & $11,460 \mathrm{~kg}$ \\
\hline Transuranic & $3 \mathrm{~m}^{3}$ \\
\hline Solid low-level & $1793 \mathrm{~m}^{3}$ \\
\hline Liquid low-level & $1534 \mathrm{~m}^{3}$ \\
\hline Process & $270,000 \mathrm{~m}^{3}$ \\
\hline Industrial/Sanitary/ & $11,920 \mathrm{~m}^{3}$ \\
\hline
\end{tabular}

\subsubsection{Tracking Systems}

A detailed system for tracking progress toward generators' goals will be developed. Routine feedback will be provided to division management, WRRs, and ORNL management.

To effectively monitor waste reduction progress, ORNL waste tracking systems need further development for each category of waste. A computerized data base has been used for tracking hazardous and mixed wastes from the point of generation to ultimate disposal since 1986. Data originate from the "Request for Disposal" (RFD) form completed by the generator and are logged into the data system. The data system has file maintenance capabilities, record query, and report generation functions. It is used primarily for record keeping, (prior to fiscal year (FY) 1990 as part of the charge-back system) monthly billing of costs to waste generators, shipping manifest generation, disposal records, and report preparation.

The primary contribution of the waste tracking system to the waste reduction effort is in establishing generator accountability. For solid waste streams, the database provides waste generation records sortable by division and individual generator.

In addition to the waste tracking system discussed above, a data system, the Hazardous Material Inventory System (HMIS) is being implemented to track hazardous materials from procurement to the user. The HMIS - Procurement Interface will:

(1) provide for additional review and approval for extremely hazardous materials by a trained professional prior to release of a purchase 
requisition. Part of the review will consist of justification for large quantities of material, and recommending less hazardous substitutes, and

(2) a quarterly management report will be generated that compares the receipts of hazardous materials by each division over time. This information can then be used for waste reduction purposes to track progress in waste reduction.

The HMIS will also allow customers to "shop" in other laboratories' inventories within their division in order to reduce the volume of new chemicals purchased and allow for consumption of chemicals already on the shelf prior to their expiration.

The Solid Waste Information Management System (SWMMS) is a data base for tracking SLLW and TRU waste. The data processed at ORNL in the SWIMS is included in the DOE-wide Integrated Database (IDB). Tracking information for the SWIMS is obtained from a RFD before the waste is accepted.

A plan for a new integrated multi-user data base for tracking waste is being developed. User needs identified in the "Waste Information Systems Evaluation" will be considered in the development of the new tracking system.

Tracking and accounting systems are being developed for all waste categories. However, particularly for liquid and gaseous wastes, lack of flow monitoring capabilities at the generator site will limit accuracy for tracking progress toward divisional goals.

\subsection{WASTE MANAGEMENT COST ACCOUNTING}

Prior to FY 1990, ORNL utilized a cost accounting system whereby waste generators were directly charged for the costs of managing their wastes $\left(\$\right.$ per $\mathrm{kg}$ or $\left.\mathrm{m}^{3}\right)$. However, this system remains in effect for only a few generators. Through the Environmental Restoration and Waste Management Five-Year Plan, waste generating programs contribute funds at the DOE-HQ level. The amount collected from each program is determined according to the quantity of waste it generated during the prior fiscal year. Waste collection and management is then paid for from this pool of funds. Generators are not directly charged for the waste that is generated. In addition, budgeting for waste management costs is identified in the ORNL Elements of Cost form prepared for all programmatic work.

\subsection{QUALITY ASSURANCE (QA)}

QA program objectives and methods from DOE Order 5700.6B are incorporated into the ORNL Waste Reduction Program. Program audits will be conducted periodically. 


\section{WASTE REDUCTION ACTIVITIES}

\subsection{WASTE REDUCTION INCENTIVES}

Besides the legal mandates, DOE orders, regard for healti, safety and the environment, the waste generators at ORNL have other incentives to reduce waste.

\subsubsection{DOE-OR Waste Minimization Awards}

In order to recognize outstanding achievements and raise contractor employee awareness in the critical area of waste minimization, DOE-OR has implemented an annual OROwide Waste Minimization Award Program. The award is presented to an individual or group who has implemented a waste reduction measure. The award selection criteria are based on innovation, measurability of results, and projected cost savings in reducing the amount of low-level, TRU, mixed, or hazardous wastes being generated. This is presented by DOE-OR management as a waste reduction incentive.

\subsubsection{ORNL Waste Reduction Suggestion Program}

As part of the ORNL Waste Reduction Incentive Program, an award program will be established to encourage all employees to generate waste reduction ideas. The managers of the PPAP and ALARA programs have planned similar awards for suggestions in their areas. These award programs may be combined.

\subsection{SPECIFIC EXAMPLES OF WASTE REDUCTION AT ORNL}

\subsubsection{Waste Avoidance/Volume Reduction}

Each division, through their WRRs, has been asked to examine existing processes to discover methods to reduce the volume or toxicity of their waste streams. Material substitution, process procedure change, or changing to a new process are all methods to be used to avoid the generation of wastes. Since most mixed wastes can only be stored, waste stream segregation techniques are to be applied to avoid the generation of mixed wastes, wherever possible. New projects are to be evaluated with waste avoidance measures in the process design. The division WRRs play a key role in these waste avoidance activities. Examples of projects which have been or are being implemented are given in the following paragraphs.

Although cooling water from Building 3001 requires no treatment prior to release, it traditionally has been discharged to the process waste system. Maintenance and surveillance personnel suggested and implemented valving changes to divert the cooling water from the process waste system. Elimination of this cooling water from the process waste system helped relieve the hydraulic loading on the Process Waste Treatment Plant (PWTP). In addition to 100,000 gal per year of waste 
avoidance, the cost savings associated with this waste reduction suggestion was approximately $\$ 8,000$ annually. (This project received the DOE-OR Waste Minimization Award for 1989.)

A total of 472 55-gal drums of low specific activity (LSA) waste material was supercompacted by a commercial vendor to reduce the volume of waste by 70 percent and better utilize the expensive and limited tumulus vault space. The drums of uncompacted waste would have occupied approximately $3,540 \mathrm{ft}^{3}$. Supercompacted drums and resulting solidified liquid occupy only $1,070 \mathrm{ft}^{3}$ of tumulus storage space. Including the cost of the vendor contract to compact the waste, this project saved approximately $\$ 224,500$ and $2,470 \mathrm{ft}^{3}$ of tumulus storage space. Supercompaction is expected to be a continuing effort, with drums of LSA waste collected and supercompacted about once a year.

\subsubsection{Recycling and Reuse}

Avoidance of disposal costs and conservation are motivators for recycling through reuse, swapping, off-site sales, and recovery. Throughout ORNL, recycling methods are encouraged and rewarded through the incentive programs. The following cites recycling plans and some successes.

1. In 1990 and early 1991, recycling programs for office paper, aluminum cans, and corrugated cardboard were implemented. Diversion of these streams from the landfill has been a high priority, since the projected fill date for the landfill precedes the availability of its successor. Reuse and recycling of other sanitary waste streams, such as wood, are also being evaluated.

2. One of the most successful waste reductions at ORNL has been the reuse of unexpired surplus chemicals. At one time, unused commercial chemicals constituted 90 percent of the waste chemicals collected at ORNL. Approximately 30 percent of these containers were unopened. Lists of reusable chemicals were circulated by the Hazardous Waste Operations Group to chemical users. Many of these chemicals, which were no longer needed by their owners, have been transferred to new owners for use?.

During CY 1989, the F\&M Division received numerous chemicals, paint, roofing sealant, used cooking oil, outdated chemicals, and other hazardous materials. Instead of disposing of the hazardous materials at a cost of $\$ 300,000$, Finance and Business Management (F\&BM) Division employees developed the idea of on-site sales and donations. Some of the paint was donated to Roane State Community College and some of the chemicals to the University of Tennessee. The remainder of the excess materials was purchased by local businesses at the on-site sale. This practice reduced not only generation of 
hazardous waste requiring disposal, but also raw materials required by the second-generation owners.

3. Reuse of lead, which if declared waste would be a regulated RCRA metal, is encouraged. By segregating lead from radioactive wastes, the uncontaminated metal can be reused. A fabrication shop at ORNL has been used to remold the recycled lead according to user needs. The feasibility of decontaminating radioactively contaminated lead is also being pursued. Decontaminated lead will be reused.

4. Other metals have been recycled through scrap metal sales. In this program, excess metnls have been sold to private sector organizations for reuse. While not all of the material involved would be considered hazardous waste if it were to be discarded instead of recycled, some of the metals would be regulated by RCRA if handled as waste products. This effort resulted in recycling 737 tons of scrap metal in 1987 and 825 tons in 1988. In 1989, largely as a result of cleanup activities in preparation for a Technical Safety Assessment (TSA) audit, this total increased to 1,004 tons.

5. As a PIP project, the Environmental Sciences Division (ESD) investigated the substitution of 100 percent recycled paper for computer output paper instead of virgin paper. For three months (November 1989 to February 1990), ESD used recycled paper to ensure that it performed with the same quality as the virgin paper. By substituting recycled paper for virgin paper, ESD is creating a market for recycled paper, conserving natural resources, and protecting the environment by reducing generated pollution. The recycled computer paper has the added benefit of costing 1/3 the price of virgin paper. (This PIP Project received the Martin Marietta President's Award for Performance Improvement.)

6. As a PIP project, the Plant and Equipment Division is investigating the reuse of used motor oil. The spent oil from routine oil maintenance on ORNL vehicles would be burned for its heating value. During the winter months, the used oil would be the fuel source for space heaters at the ORNL garage.

\subsubsection{Material Substitution}

Each division has been encouraged to consider substitution, where practical, of less hazardous or less toxic chemicals in processes and experiments. Often substitution affects research quality and cannot be implemented. However, material substitution where possible results in generation of less toxic waste which is less costly to manage conse quently. The following are examples of material substitution.

1. The ESD performs toxicity tests with minnow larvae and micro-crustaceans to evaluate stream and wastewater quality. The health of these populations had 
been periodically evaluated using cadmium chloride as the reference toxicant. After some research of the test protocol, sodium lauryl sulfate, a major constituent of soap, has been substituted for the cadmium chloride. This substitution resulted in a waste that is safe to dispose of in the process waste system and eliminated the production of a hazardous waste.

2. The substitution of aqueous scintillation fluids, which are not RCRA-regulated, for those currently used by ORNL researchers was studied as part of a programmatically funded task during $1988^{10}$. A number of laboratories at ORNL have substituted the non-RCRA scintillation fluids. In most cases, the new fluids do not degrade the quality of research data, and the substitution of a medium that is not regulated under RCRA for one that is regulated as a hazardous waste has resulted in a waste stream which is amenable for discharge into municipal sewer systems.

\subsubsection{Inventory Management (Procurement Control)}

Control of procurement of chemicals can prevent excessive inventories, which if the chemicals exceed their shelf life before they are used could require costly disposal. Therefore, it is a best management practice to substitute less hazardous or toxic materials during the procurement process.

One of the most important aspects of a procurement control system is purchasing only the quantities required. Buying bulk quantities of chemicals may be less expensive initially, but the higher cost incurred in disposing of the unneeded volume must also be considered. Therefore, each division is encouraged to review new purchase requisitions and compare them to their present stock. This prevents overstocking of chemicals.

As part of the Accelerated Vendor Inventory Delivery System (AVID), all Class III and IV hazardous chemicals require management approval before they can be purchased. Justification or an explanation may be required for large quantities of materials. This will help to reduce waste at the source. Personnel involved in the inventory and procurement efforts are trained in safety and waste reduction techniques.

\subsubsection{Material Substitution and Process Modifications}

Waste reduction measures vary from small scale modifications in sume programs to broad changes in others. Since ORNL waste generators are primarily numerous small laboratory or research programs, decreasing the volume of waste being generated often involves reductions which, taken by themselves, are apparently small changes in the total volume. However, in terms of quantity of waste produced from that particular program, the savings in waste volumes can be substantial. The following programs are excellent examples: 
1. From 1985 to 1987 , a waste reduction program reduced the generation rate of LLLW concentrate to approximately $95 \mathrm{~m}^{3} / \mathrm{y}$. Further reduction in 1988 and 1989 brought generation to approximately $49 \mathrm{~m}^{3} / \mathrm{y}$. This was accomplished by a decrease in the generation rate of LLLW at the source and an increase in the evaporation efficiency of the LLLW evaporators from a volume reduction factor of about 9:1 to 30:1. Waste reduction efforts were accomplished by a series of projects and process changes, including the addition of a clarifier to the PWTP.

2. The Liquid and Gaseous Treatment Technology Group (LGTTG) is taking a unique approach to reduction of radioactive liquid wastes by developing the means to analyze the overall ORNL liquid waste system. By developing a model of the overall liquid waste system, the group has created a method to assess the impacts that each portion of the system has on composition and volume of final waste produced for permanent disposal at ORNL. This is the first attempt at ORNL to determine what effects each generator and treatment operation (whether at the source or in the centralized treatment facilities) has on the final waste form and to implement waste reduction projects accordingly.

The LGTTG's new approach is effectively reducing the total amount of waste generated by the liquid waste system, with particular emphasis on reduction of liquid low level waste concentrate (LLLWC).

The group performed the first comprehensive survey of liquid waste generators to determine the amount and type of waste being generated at ORNL and where these streams are presently being routed for treatment. This information was coupled with a technical analysis of the waste treatment facilities to determine where improvements could be made in the waste system which would result in major reduction in the final waste generation rates. Characterization aid treatability studies are being performed to support implementation of such projects to reduce final waste generation rates by (1) treatment at the generation site, (2) modification of the processes generating the waste, and/or (3) improved operations at the centralized facilities.

Results of the systems analysis show that only three current operations at ORNL significantly impact the hazardous nature or the amount of LLLWC. The major contributors to the LLLWC are the PWTP and the Radiochemical Engineering Development Center (REDC) Facility. The LGTTG is focusing waste reduction efforts in these areas since they significantly affect LLLWC generation. Since the PWTP is the single largest contributor to the LLLWC, projects have emphasized the upgrade of this facility. Projects are also in progress which will reduce waste generation at REDC in the near future.

The systems analyses established that installation of an extra holding tank in the PWTP evaporator loop will reduce the LLLWC by 4,000 gal/year. This $\$ 30,000$ 
project is in the process of being implemented and will save $\$ 200,000 / y e a r$ in waste disposal costs.

The generator survey identified several once-through cooling water streams which are being fed to the PWTP for radionuclide removal. These streams account for 35 percent of the PWTP feed and a corresponding percentage of the secondary waste generated at the plant. Minor piping modifications are being made to segregate these waste streams which will reduce the SLLW production by $1,400 \mathrm{ft}^{3}$ annually (33 percent of the present generation rate) and LLLWC by an additional $1,300 \mathrm{gal}$ (from $4,000 \mathrm{gal}$ to $2,700 \mathrm{gal}$ ). The cost savings for this project are estimated to be $\$ 120,000$ each year.

While many previous "waste reduction" projects have reduced the volume of waste entering a given phase of the liquid waste treatment system, they often have little impact on volumes or compositions of the final waste steams which must be treated for permanent disposal. The LGTTG's systems analysis approach is assuring that waste reduction projects are implemented which will be cost effective and significantly reduce the amount of waste being stored for ultimate disposal.

\subsubsection{Waste Segregation}

Segregation of wastes (e.g. hazardous wastes and radioactive wastes) improves waste management and waste reduction efforts.

1. A program for management of lead has been instituted at ORNL. The training program described in Sec. 5.1 stresses the segregation of hazardous waste, particularly lead, from radioactive waste.

2. In 1989 as part of a systems analysis, Chemical Technology Division developed a pH segregation system to separate metals-containing wastewater from "clean" wastewater. Using the $\mathrm{pH}$ segregation system could reduce the amount of wastewater treated for heavy metals at the Nonradiological Wastewater Treatment Plant (NRWTP) to about $15,000 \mathrm{gal} / \mathrm{week}$, significantly reducing sludge production and reducing the hydraulic loading of the NRWTP. Using sludge production data from the pilot plant testing for the NRWTP, the pH segregation system will reduce sludge production by a factor of 100 .

\subsection{LABORATORY CLEANOUTS}

Laboratory cleanout, the removal of old or unnecessary chemicals from a laboratory, is encouraged for a number of reasons aside from good housekeeping. First, clearing the work area of unneeded chemicals reduces health and safety risks. Some chemicals on 
laboratory shelves may be as old as $\mathbf{4 0}$ years. Additional hazards are associated with aging of some chemicals, such as picric acid and ethers, which can become explosive.

Second, eliminating materials associated with expired research projects helps clear the waste generation record for current and future activities in the laboratory. One of the difficulties encountered in measuring progress in waste reduction is accounting for disposal of wastes from projects terminated in prior years. Including waste disposal costs in initial project planning will help alleviate this problem in the future and eliminate the problem of legacy wastes. Also, disposal of unneeded chemicals will be more costly in the future than today. Delaying the cleanout and disposal will only increase the costs.

Of the approximately $143,089 \mathrm{~kg}$ of waste ORNL managed as hazardous and mixed (RCRA wastes are a portion of this amount) during 1990, approximately $28,614 \mathrm{~kg}$ were generated from the cleanout of laboratories. During 1990, a Laboratory-wide inventory of chemicals was initiated to identify chemicals for which the shelf life had expired. These were disposed of using established and approved procedures.

\section{WASTE REDUCTION AWARENESS}

\subsection{EMPLOYEE TRAINING}

The waste generator training program includes several courses offered to programs and divisions which produce hazardous or radioactive wastes. Additionally, a training program will be presented in CY 1992 which will address industrial and sanitary wastes. In general, these training sessions are designed to instruct the waste generator personnel in the proper techniques for waste segregation, certification, reduction, and packaging, and in the applicable procedures and documentation for waste handling and disposal.

The first training module was designed for SLLW generators to instruct them on the methods and documentation to be used by generator of SLLW in order to generate waste forms consistent with the WAC in order for the Radicactive Solid Waste Operations staff to collect and dispose of solid low-level radioactive wastes.

Because of the problems which have been or may be encountered in managing mixed wastes, a major portion of this program is devoted to methods for reducing the quantity of mixed waste being generated, primarily focusing on segregation of radioactive wastes from hazardous wastes. Successful completion of this training and biennial re-training is mandatory for being recognized as a radioactive waste generator.

Another program is directed toward hazardous and mixed waste generators, describing the procedures and requirements for managing those wustes at ORNL. This training course addresses such topics as identification of hazardous waste, management of accumulation areas, and minimizing the amount of waste being generated. 
A training program specifically for waste reduction techniques was developed in 1988. This course describes some of the problems in waste management, explains the impetus behind implementing the waste reduction program, and includes a classroom exercise in identifying waste streams to which waste reduction techniques could be applied. This training is currently being modified to a workshop format and will be offered to the WRRs in an effort to assist them in the generation of waste reduction plans and in conducting PWAs. A training module will be prepared to inform the total population at ORNL.

In addition, waste reduction principles will be added to General Employee Training, which is required for all ORNL employees and on-site contractors.

\subsection{COMMUNICATIONS}

Meetings with the division WRRs is one of the vehicles used to pass information on waste reduction from the Waste Reduction Coordinator or from WRRs in other divisions to the generators in the representative's division. Transfer of waste reduction ideas or discussion of waste reduction problems is encouraged. Notes from the meetings are sent to the representatives with current waste reduction documents or news.

Waste reduction posters have been distributed to all the WRRs and displayed within their divisions. The goal is to promote employee awareness in the everyday work environment. Seminars and videotape sessions on current waste reduction technology and issues are being planned. The ORNL Recycler, which contains information about recycling activities onsite, as well as tips for reducing waste at home, is distributed to all employees bimonthly. Internal publications and bulletin boards will be used to further employee awareness.

\section{TECHNOLOGY TRANSFER}

An important aspect of ORNL's waste reduction philosophy is the transfer of information about our waste reduction efforts to other facilities, organizations and industry. The following mechanisms are examples of how waste reduction technology can be successfully transferred:

o participate in the Environmental Restoration and Waste Management waste reduction workshops which includes attendees from other DOE facilities

o provide input to the WIN waste reduction bulletin board

o exchange information with the University of Tennessee Center of Industrial Services

- transfer waste reduction technology successes with the EPA Pollution Prevention Information Clearinghouse and the Waste Reduction Resource Center of the Southeast 
In the past, for example, ORNL has provided information on waste reduction training and our inactive charge-back system to other DOE contractors.

\section{WASTE REDUCTION PROGRAM EVALUATION}

As budgets permit, the ORNL Waste Reduction Program will be routinely evaluated. The evaluation will include all aspects of the program, including whether completed projects have achieved intended goals. Updates, as appropriate, will be made to this plan to provide a current, accurate description of the Waste Reduction Program. 


\section{REFERENCES}

1. DOE Order 5820.2A, "Waste Management Documentation Requirements," September 26, 1988.

2. DOE Order 5400.1, "General Environmental Protection Program," November 9, 1988.

3. DOE Order 5400.3, "Hazardous and Radioactive Mixed Waste Program," February 22, 1989.

4. Resource Conservation and Recovery Act, "Waste Minimization Amendment," November 1984.

5. ORNL ES\&H Management Plan for Oak Ridge National Laboratory, December 1991 (draft).

6. DOE Waste Minimization Guidance for Process Waste Assessments, November 1990, (draft).

7. U.S. Environmental Protection Agency, EPA/625/7-88/003, Waste Minimization Opportunity Assessment Manual, July 1989.

8. Homan, M. D. et. al., Waste Reduction Program at Oak Ridge National Laboratory During CY 1990, ORNL/TM-11780, March 1991.

9. Smith, M. A., Hazardous Waste Minimization At Oak Ridge National Laboratory During 1988, ORNL/TM-11109, March 1989.

10. Kimbro, A. R., Scintillation Cocktail Replacement Study, ORNL/CF-89/31, January 1989. 
Appendix A

\section{WASTE REDUCTION POLICY \\ for the \\ OAK RIDGE NATIONAL LABORATORY}

It is the policy of Oak Ridge National Laboratory to protect the environment and human health by the safe use and management of its resources. To this end, all forms of pollution will be prevented at the source whenever and wherever fasible. Waste materials that cannot be eliminated by source reduction will be minimized to the extent feasible; waste that still exists will be recycled, reused or reclaimed. Waste that is nevertheless generated, will be treated to reduce the volume, toxicity or mobility prior to disposal. Reducing or eliminating the generation of waste will be given prime consideration in research, process design and plant operations.

This policy will be implemented by all Laboratory employees and coordinated by the Waste Reduction Program in the Office of Waste Management and Remedial Actions. The goal of the program will be to systematically eliminate or reduce the generation of waste from site operations. The program will seek to make source reduction and environmentally sound recycling an integral part of the philosophy and operations of this organization. It will also seek to develop in all employees, an awareness of environmental problems and encourage their participation in minimizing the generation of waste and responsibly using resources.

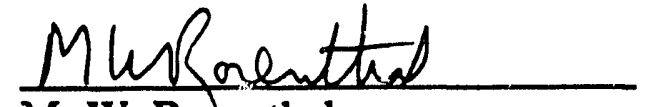

M. W. Rosenthal

Deputy Director,

Oak Ridge National Laboratory

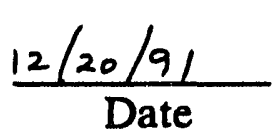


APPENDIX B: Simplified Organizational structure for Waste Reduction at ORNL

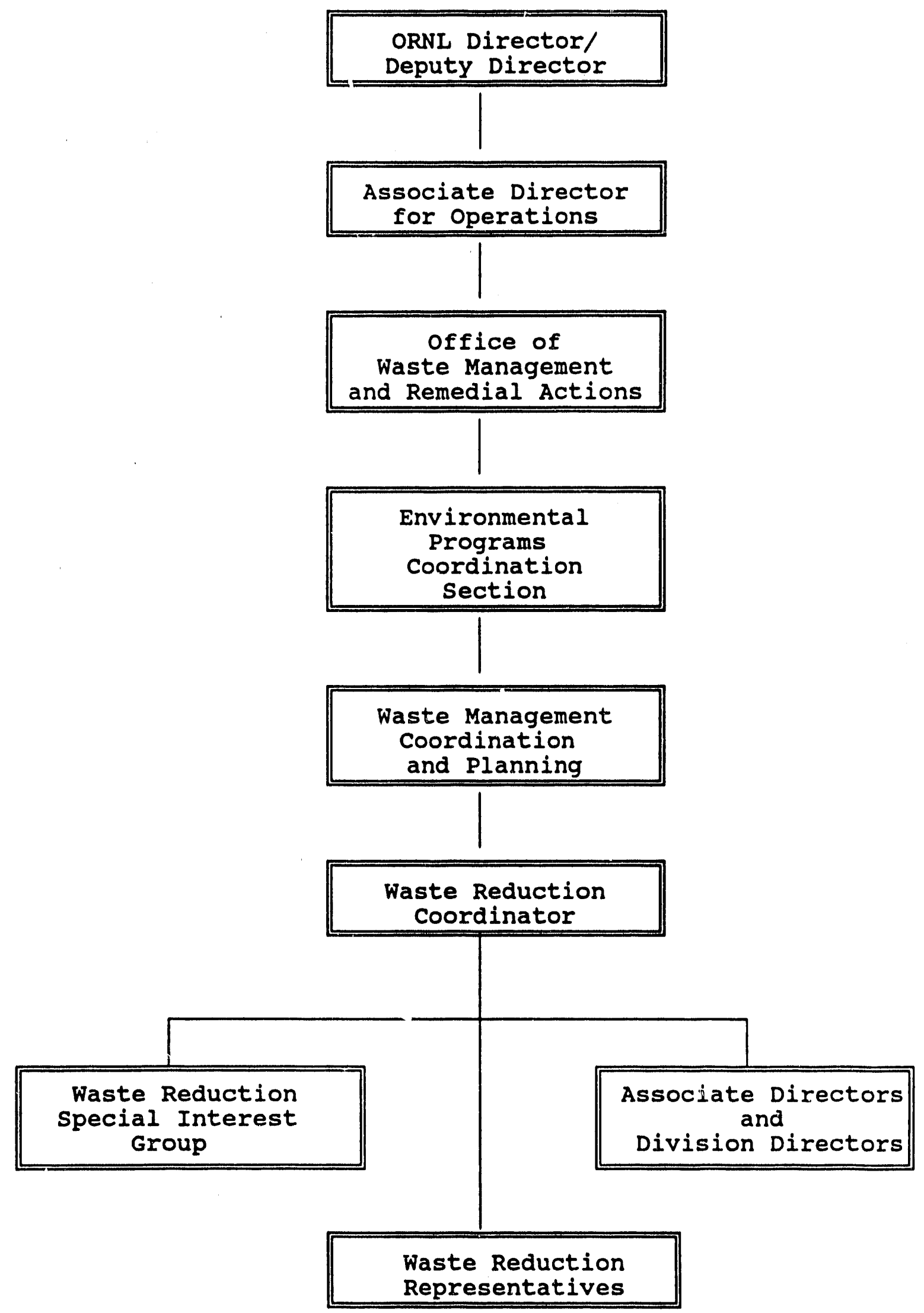


1. J. F. Allred

2. B. R. Appleton

3. J. K. Bain

4. J. B. Ball

5. P. T. Barton

6. J. K. Bryson

7. R. S. Carlsmith

8. P. N. Coffey

9. B. L. Corbett

10. K. A. Cummings

11. L. B. Dunlap

12. B. G. Eads

13. K. L. Felker

14. R. E. Fenstermaker

15. L. M. Ferris

16 M. K. Ford

17. W. Fulkerson

18. T. A. Gabriel

19. M. D. Galloway

20. A. S. Garrett

21. R. K. Genung

22. H. A. Glovier

23. J. A. Green

24. F. C. Hartman

25. D. R. Henderson

26. M. S. Hendricks

27. J. N. Herndon

28. F. J. Homan

29. R. B. Honea

30. J. L. Johnson

31. J. E. Jones

32. E. R. Kackenmester

33. S. V. Kaye

34. C. M. Kendrick

35. W. W. Koch

36. M. W. Kohring

37. F. C. Kornegay

38. W. C. Kuykendall

39. A. P. Malinauskas

40. L. N. McCold

41. L. E. McNeese

42. S. A. Meacham

43. S. R. Michaud
44. G. D. Mills

45. J. R. Montgomery

46. O. B. Morgan

47. J. M. Morton

48. G. W. Oliphant

49. D. E. Pierce

50. R. G. Pope

51. M. L. Poutsma

52. G. E. Proffitt

53. C. E. Pugh

54. W. J. Redmond

55. D. E. Reichle

56. J. B. Richard

57. C. R. Richmond

58. J. B. Roberto

59. T. H. Row

60. A. C. Schaffhauser

61. J. Sheffield

62. R. B. Shelton

63. B. V. Shelton

64. W. D. Shults

65. N. L. Sinor

66. G. E. Smith

67. J. O. Stiegler

68. L. E. Stokes

69. J. H. Swanks

70. C. S. Travaglini

71. L. L. Triplett

72. A. W. Trivelpiece

73. R. I. Van Hook

74. R. C. Ward

75. D. A. Waters

76. C. D. West

77. G. G. Wilson

78. S. D. Wright

79. A. Zucker

80. Central Research Library, ORNL

81. ORGDP Library

82-83. ORNL Laboratory Records

84. ORNL Laboratory Records - RC

85. Y-12 Technical Library

86. ORNL Patent Office 


\section{EXTERNAL DISTRIBUTION}

87. Office of Assistant Manager for Energy Research and Development, DOE Field Office, Oak Ridge, P.O. Box 2001, Oak Ridge, TN 37831

88-97. Office of Scientific and Technical Information, U.S. Department of Energy, P.O. Box 62, Oak Ridge, TN 37831 

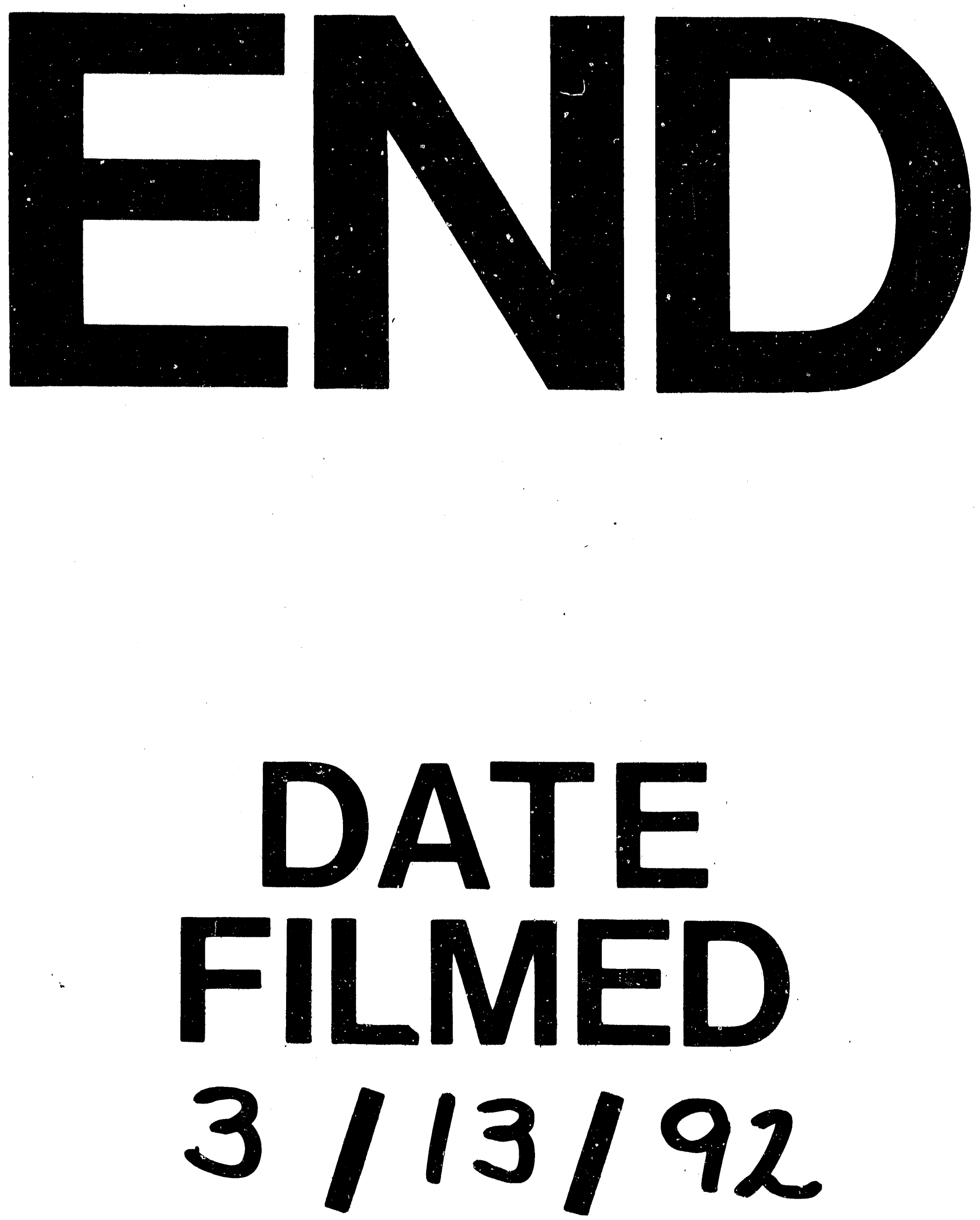
